Hydrology and Earth System Sciences, 7(3), 411-422 (2003) C EGU

\title{
The response of a small stream in the Lesni potok forested catchment, central Czech Republic, to a short-term in-stream acidification
}

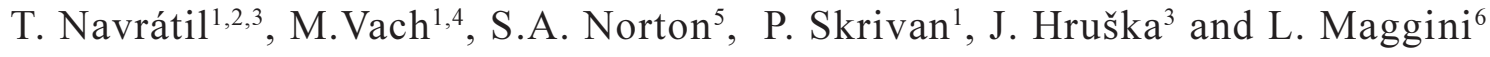

${ }^{1}$ Geological Institute, Academy of Sciences, Rozvojová 135, Praha 6 - Suchdol, 165 00, Czech Republic

${ }^{2}$ Faculty of Science, Charles University, Albertov 6, Praha 2, 128 43, Czech Republic

${ }^{3}$ Czech Geological Survey, Klárov 3, Prague 1, 118 21, Czech Republic

${ }^{4}$ Faculty of Forestry, Czech University of Agriculture, Kamýcká 129, Prague 6, 165 21, Czech Republic

${ }^{5}$ Department of Geological Sciences, University of Maine, Orono, Maine 04469-5790, USA

${ }^{6}$ Department of Geology, University of Lausanne, Lausanne, CH-1015, Switzerland

Email for corresponding author: navratilt@gli.cas.cz

\begin{abstract}
Lesni Potok stream drains a forested headwater catchment in the central Czech Republic. It was artificially acidified with hydrochloric acid $(\mathrm{HCl})$ for four hours to assess the role of stream substrate in acid-neutralisation and recovery. The pH was lowered from 4.7 to 3.2. Desorption of $\mathrm{Ca}$ and $\mathrm{Mg}$ and desorption or solution of Al dominated acid-neutralisation; Al mobilisation was more important later. The stream substrate released 4,542 meq Ca, 1,184 meq $\mathrm{Mg}$, and 2,329 meq Al over a $45 \mathrm{~m}$ long and $1 \mathrm{~m}$ wide stream segment; smaller amounts of $\mathrm{Be}, \mathrm{Cd}, \mathrm{Fe}$, and $\mathrm{Mn}$ were released. Adsorption of $\mathrm{SO}_{4}{ }^{2-}$ and desorption of $\mathrm{F}^{-}$occurred during the acidification phase of the experiment. The exchange reactions were rapidly reversible for $\mathrm{Ca}, \mathrm{Mg}$ and $\mathrm{SO}_{4}{ }^{2-}$ but not symmetric as the substrate resorbed 1083, 790 and $0 \mathrm{meq} \mathrm{Ca}, \mathrm{Mg}$, and $\mathrm{Al}$, respectively, in a 4-hour recovery period. Desorption of $\mathrm{SO}_{4}{ }^{2-}$ occurred during the resorption of $\mathrm{Ca}$ and $\mathrm{Mg}$. These exchange and dissolution reactions delay acidification, diminish the $\mathrm{pH}$ depression and retard recovery from episodic acidification. The behaviour of the stream substrate-water interaction resembles that for soil-soil water interactions. A mathematical dynamic mass-balance based model, MASS (ㅆodelling $\underline{\text { Acidification }}$

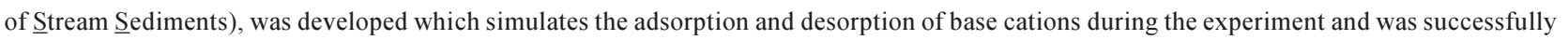
calibrated to the experimental data.
\end{abstract}

Keywords: Al, $\mathrm{Ca}, \mathrm{Mg}$, base cations, acid-neutralisation, stream acidification, recovery, stream sediment, experiment, modelling, adsorption, desorption, adsorption, Czech Republic, Lesni Potok

\section{Introduction}

Episodic changes in stream chemistry occur during snowmelt and rainstorm events. In many streams, episodic acidification is caused by a combination of base cation dilution and the release of natural acidity (organic acids, salt effects, and $\left.\mathrm{NO}_{3}{ }^{-}\right)$, and anthropogenic acidity $\left(\mathrm{SO}_{4}{ }^{2-}\right.$ and $\left.\mathrm{NO}_{3}^{-}\right)$. Commonly, one or more strong acid anions $\left(\mathrm{Cl}^{-}, \mathrm{NO}_{3}\right.$, $\mathrm{SO}_{4}{ }^{2-}$ ) increase. The episodic chemical changes include short-term decreases of $\mathrm{pH}$ and acid neutralising capacity (ANC) and increases of ionic Al. The importance of the effects of episodic acidification on in-stream processes has been underestimated in modelling and empirical studies.
Several in-stream acidification experiments have clarified some of the important chemical processes, including adsorption, desorption, and dissolution occurring within the stream itself. Hall et al. (1980) were the first to study the ecological response of a stream to experimental addition of acidity $\left(\mathrm{H}_{2} \mathrm{SO}_{4}\right)$ during six months of low flow. They demonstrated that the fluxes of $\mathrm{Ca}, \mathrm{Mg}, \mathrm{K}, \mathrm{Na}$, and $\mathrm{Al}$ are increased as a consequence of depressing the $\mathrm{pH}$ to about 4. Other experiments (Norton et al.; 1987, 1992, 2000; Tipping and Hopwood, 1988; Hedin et al., 1990; Hruška et al., 1999) used $\mathrm{HCl}, \mathrm{HNO}_{3}$, or $\mathrm{H}_{2} \mathrm{SO}_{4}$. The latter two studies focused on the effects of in-stream acidification on organic 
acidity. Three general processes have been documented for interaction between the acidifying stream water and sediment. Firstly and most importantly, $\mathrm{H}^{+}$exchanges with other cations adsorbed on the stream substrate, releasing them into solution. Secondly, adsorption of $\mathrm{SO}_{4}{ }^{2-}$ by stream substrate may occur. Thirdly, dissolution of an Al-rich solid phase occurs, along with trace elements associated with that phase. These reactions are generally reversible during recovery (Norton et al., 2000).

This paper describes the results of an in-stream acidification of a small first-order stream (Lesni Potok) on granite bedrock, in the central Czech Republic; evaluation of the effects of acidification on the reversible release of base cations $(\mathrm{Ca}, \mathrm{Mg}, \mathrm{K}, \mathrm{Na})$, trace elements, and $\mathrm{Al}$ and $\mathrm{Be}$, and the effect of changing $\mathrm{pH}$ on $\mathrm{SO}_{4}^{2-}$ sorption is included. The mechanisms of the in-stream acid neutralisation are described and compared with the findings of several other studies (Norton et al., 2000; Hruška et al., 2002; Navrátil, 2000). A numerical model describing the adsorption and desorption processes controlling the base cation stream chemistry during the acidification experiment has been developed.

\section{Methods}

\section{SITE DESCRIPTION}

The Central Czech Republic received very acidic deposition in the 1980s but by the late 1990s, the acidity of deposition had decreased substantially (Kopácek et al., 2001; Hruška et al., 2002). This history makes Lesni Potok (henceforth LP) an important 'case study' site for detecting changes in chronic and episodic acidification of surface waters. The LP catchment covers $0.765 \mathrm{~km}^{2}$ and is located some $30 \mathrm{~km}$ east-southeast of Prague. Soils, mostly Gleyic or Dystric Cambisols, are derived from the Rícany Granite. The lower part of the catchment is underlain by 4 to $5 \mathrm{~m}$ of sediment. The forest vegetation is $46 \%$ Norway spruce (Picea abies) and 54\% European beech (Fagus sylvatica). The mean annual bulk precipitation from 1994-2000 was $600 \mathrm{~mm}$ and the corresponding runoff was $68 \mathrm{~mm}$. High evapotranspiration is typical of the area and relatively high concentrations of conservative elements such as $\mathrm{Cl}$ result. The evapotranspiration rate based on the water budget is $89 \%$, and about $85 \%$ based on the $\mathrm{Cl}$ budget. The annual average air temperature is $7^{\circ} \mathrm{C}$. Stream discharge was determined at a Thomson weir at $400 \mathrm{~m}$ a.s.l. The highest point in the catchment is $495 \mathrm{~m}$ a.s.l.

The deposition of $\mathrm{SO}_{4}^{2-}$ on this area of the Czech Republic has decreased significantly since 1990 (Kopácek et al. 2001; Hruška et al. 2002). At LP catchment, the annual bulk deposition of $\mathrm{SO}_{4}^{2-}$ declined from $58 \mathrm{meq} \mathrm{m}^{-2}$ in 1994 to $12 \mathrm{meq} \mathrm{m}^{-2}$ in year 1999, while the mean concentration of $\mathrm{SO}_{4}{ }^{2-}$ in precipitation decreased from $90 \mu \mathrm{eq} \mathrm{\textrm {L } ^ { - 1 }}$ in 1994 to $29 \mu$ eq L $\mathrm{L}^{-1}$ in 1999 (Table 1). Correspondingly, the annual deposition of $\mathrm{SO}_{4}^{2-}$ in beech and spruce throughfall declined from $191 \mathrm{meq} \mathrm{m}^{-2}$ in 1994 to $51 \mathrm{meq} \mathrm{m}^{-2}$ in 1999 , while dry deposition of $\mathrm{SO}_{4}^{2-}$ declined from 2.5 to 1.8 times bulk deposition.

Shallow groundwater was sampled from a $5 \mathrm{~m}$ deep well adjacent to the weir. The lower $0.5 \mathrm{~m}$ of the plastic casing was perforated and the well sampling water at least $2 \mathrm{~m}$ below the groundwater level. The shallow groundwater at LP had high concentrations of $\mathrm{Ca}^{2+}, \mathrm{Na}^{+}, \mathrm{Cl}^{-}, \mathrm{H}_{4} \mathrm{SiO}_{4}$, $\mathrm{Mn}^{2+}$ and $\mathrm{Fe}^{2+} ; \mathrm{pH}$ was near neutral (6.6) (Table 1). The high concentrations of $\mathrm{Ca}^{2+}, \mathrm{Na}^{+}$and $\mathrm{H}_{4} \mathrm{SiO}_{4}$ originated from weathering of plagioclase. High evapotranspiration explains, in part, high concentrations of many solutes in the groundwater and stream water. The concentrations of $\mathrm{Al}^{\mathrm{n}+}$, $\mathrm{Be}^{2+}$ and $\mathrm{Cd}^{2+}$ are low because of the nearly neutral $\mathrm{pH}$ value. The relatively high concentrations of $\mathrm{Mn}^{2+}$ and $\mathrm{Fe}^{2+}$ are a result of partial anoxia in the groundwater more than $2 \mathrm{~m}$ below the groundwater table. During periods of low discharge (usually in summer and autumn), the surface water chemistry is very similar to that of shallow groundwater (Table 1).

The major cations in the LP surface water during 1999 were $\mathrm{Ca}^{2+}(45 \%), \mathrm{Mg}^{2+}(31 \%), \mathrm{Na}^{+}(22 \%)$ and $\mathrm{K}^{+}(2 \%)$ (Table 1). Eighty-eight percent of the strong acid anion (SAA) concentration is $\mathrm{SO}_{4}{ }^{2-}$, the remainder is $\mathrm{Cl}^{-}, \mathrm{F}^{-}$and $\mathrm{NO}_{3}^{-}$. The dissolved organic carbon (DOC) concentrations in the surface water are typically $\sim 8 \mathrm{mg} \mathrm{L}^{-1}$.

Higher discharge events during snowmelt in spring or during summer or autumn rainstorms involve shallower flow paths for much of the runoff. Stream chemistry varies substantially between high flow $\left(\mathrm{Q}>2.5 \mathrm{~L} \mathrm{~s}^{-1}\right)$, intermediate flow $\left(0.5 \leq \mathrm{Q} \leq 2.5 \mathrm{~L} \mathrm{~s}^{-1}\right)$, and low flow periods $(\mathrm{Q}<0.5 \mathrm{~L}$ $\mathrm{s}^{-1}$ ) (Table 1). As flow increases, $\mathrm{pH}$ decreases and concentrations of $\mathrm{Ca}^{2+}, \mathrm{Mg}^{2+}, \mathrm{Al}^{\mathrm{n}}, \mathrm{K}^{+}, \mathrm{Be}^{2+}, \mathrm{Cd}^{2+}, \mathrm{SO}_{4}^{2-}$, $\mathrm{F}^{-}$, and $\mathrm{NO}_{3}{ }^{-}$increase. This unusual behaviour of base cations is related to the high evapotranspiration, biomass mineralisation, and chemical weathering. Concentrations of $\mathrm{Na}^{+}, \mathrm{Cl}^{-}, \mathrm{H}_{4} \mathrm{SiO}_{4}, \mathrm{Fe}^{2+}$ and $\mathrm{Mn}^{2+}$ decreased at higher discharges.

From 1996 to 2000, the throughfall flux of $\mathrm{SO}_{4}{ }^{2-}$ decreased by nearly $75 \%$, while the average $\mathrm{SO}_{4}^{2-}$ concentration in LP surface water decreased by only $20 \%$. The stream output of $\mathrm{SO}_{4}{ }^{2-}$ in 1999 was twice the throughfall flux. Apparently, some of the $\mathrm{SO}_{4}^{2-}$ deposited in the past and adsorbed on the soils was desorbed and exported from the catchment. The reduction in mean $\mathrm{SO}_{4}{ }^{2-}$ concentration $\left(\Delta=-298 \mu \mathrm{eq} \mathrm{\textrm {L } ^ { - 1 } )}\right.$ in the surface water between the years 1994 and 1999 was 
Table 1. Numerical average values of selected parameters for the stream water of Lesni Potok catchment.

\begin{tabular}{|c|c|c|c|c|c|c|c|c|c|}
\hline & & \multicolumn{2}{|c|}{ Wet deposition } & \multirow{2}{*}{$\begin{array}{l}\text { Shallow } \\
\text { groundwater } \\
1999\end{array}$} & \multicolumn{2}{|c|}{ Stream water } & \multicolumn{3}{|c|}{ Data for $1994-2000$} \\
\hline & & 1994 & 1999 & & 1994 & 1999 & high flow & intermediate & low flow \\
\hline Q & $\mathrm{L} \mathrm{s}^{-1}$ & & & & 2.53 & 2.2 & $>2.5$ & $0.5-2.5$ & $<0.5$ \\
\hline $\mathrm{pH}$ & & 4.17 & 4.48 & 6.64 & 5.04 & 5.25 & 4.84 & 4.99 & 5.65 \\
\hline $\mathrm{Na}^{+}$ & $\mu \mathrm{eq} \mathrm{L}^{-1}$ & 10 & 14 & 670 & 381 & 395 & 346 & 370 & 410 \\
\hline $\mathrm{K}^{+}$ & $\mu \mathrm{eq} \mathrm{L}^{-1}$ & 5 & 5 & 26 & 54 & 29 & 34 & 30 & 28 \\
\hline $\mathrm{Mg}^{2+}$ & $\mu \mathrm{eq} \mathrm{L}^{-1}$ & 6 & 6 & 416 & 646 & 566 & 623 & 613 & 563 \\
\hline $\mathrm{Ca}^{2+}$ & $\mu \mathrm{eq} \mathrm{L}^{-1}$ & 28 & 19 & 1262 & 1060 & 826 & 949 & 919 & 836 \\
\hline $\mathrm{Fe}^{2+}$ & $\mu \mathrm{eq} \mathrm{L}^{-1}$ & 3 & 2 & 246 & 39 & 17 & 3 & 6 & 18 \\
\hline $\mathrm{Mn}^{2+}$ & $\mu \mathrm{eq} \mathrm{L}^{-1}$ & 0.2 & 0.2 & 31 & 15 & 10 & 7 & 7 & 15 \\
\hline $\mathrm{Al}^{3+}$ & $\mu \mathrm{eq} \mathrm{L}^{-1}$ & 6 & 5 & 1 & 92 & 83 & 84 & 79 & 55 \\
\hline $\mathrm{Be}^{2+}$ & $\mu \mathrm{eq} \mathrm{L}^{-1}$ & 0.0111 & 0.0024 & 0.03 & 1.63 & 0.82 & 1.44 & 1.22 & 0.78 \\
\hline $\mathrm{Cd}^{2+}$ & $\mu \mathrm{eq} \mathrm{L}^{-1}$ & 0.0025 & 0.0013 & 0.0004 & 0.0067 & 0.0033 & 0.0064 & 0.0059 & 0.0020 \\
\hline $\mathrm{Cl}^{-}$ & $\mu \mathrm{eq} \mathrm{L}^{-1}$ & 11 & 30 & 127 & 132 & 121 & 115 & 125 & 130 \\
\hline $\mathrm{F}^{-}$ & $\mu \mathrm{eq} \mathrm{L}^{-1}$ & 3 & 1 & 16 & 39 & 38 & 43 & 40 & 37 \\
\hline $\mathrm{SO}_{4}^{2-}$ & $\mu \mathrm{eq} \mathrm{L}^{-1}$ & 90 & 29 & 931 & 1758 & 1460 & 1700 & 1636 & 1493 \\
\hline $\mathrm{NO}_{3}^{+}$ & $\mu \mathrm{eq} \mathrm{L}^{-1}$ & 39 & 44 & 5 & 60 & 48 & 64 & 42 & 15 \\
\hline
\end{tabular}

less that the reduction in $\mathrm{Ca}^{2+}, \mathrm{Mg}^{2+}$ and $\mathrm{Al}^{3+}(\Delta=-234 \mu \mathrm{eq}$ $\mathrm{L}^{-1},-80 \mu \mathrm{eq} \mathrm{L}^{-1}$ and $-9 \mu \mathrm{eq} \mathrm{L}^{-1}$, respectively) resulting in a slight increase in the alkalinity and mean annual $\mathrm{pH}$. Fluoride and chloride remained low and relatively constant from 1994 to 1999.

\section{TREATMENT AND SAMPLING}

The acidification experiment was applied on 11th May 2001. The air and stream temperatures were $20^{\circ} \mathrm{C}$ and $11^{\circ} \mathrm{C}$ respectively. The catchment had received no precipitation for five days before the experimental treatment but $33 \mathrm{~mm}$ of rain had fallen seven days before the experiment. Discharge at the start of acidification was $2.73 \mathrm{~L} \mathrm{~s}^{-1}$ $\left(0.013 \mathrm{~mm} \mathrm{~h}^{-1}\right.$, high flow) and decreased to $2.43 \mathrm{~L} \mathrm{~s}^{-1}$ $\left(0.011 \mathrm{~mm} \mathrm{~h}^{-1}\right)$ by the end of sampling, eight hours later. Over four hours, 22 moles of $\mathrm{HCl}(4.709 \mathrm{M})$ were added to the stream, by Mariotte bottle at approximately $20 \mathrm{ml}$ $\mathrm{min}^{-1}$ at a point just below the weir. At point A, $1 \mathrm{~m}$ beyond where the acid was added, only $\mathrm{pH}$ was measured. Samples of stream water were taken concurrently at points W (weir, above where the acid was added) and at points B, C and D, respectively $20 \mathrm{~m}, 45 \mathrm{~m}$ and $70 \mathrm{~m}$ downstream from the weir. Each sampling event included three samples per site. The first was unfiltered and was used to determine total metal concentration (tot); the second was filtered through a $0.45 \mu \mathrm{m}$ cellulose membrane filter and was analysed to determine dissolved metals (dis). Both were stabilised with ultra-pure $\mathrm{HNO}_{3}$. The third sample was unfiltered and was analysed for anions.

\section{ANALYTICAL METHODS}

The $\mathrm{pH}$ was measured in situ with a calibrated portable $\mathrm{pH}$ meter (WTW 330). Concentrations of $\mathrm{Na}, \mathrm{K}, \mathrm{Mg}, \mathrm{Ca}, \mathrm{Al}$ and $\mathrm{Fe}$ were determined by flame atomic absorption spectrometry (FAAS; Perkin Elmer 3100), of F', $\mathrm{Cl}^{-}, \mathrm{SO}_{4}{ }^{2-}$ and $\mathrm{NO}_{3}^{-}$by ion chromatography (HPLC, columns Tessek HEMA-S1000 Q-L $10 \mathrm{~mm}$ ) and of Be and Cd by Graphite Furnace AAS (GFAAS, VARIAN SpectrAA 300). The speciation calculations used the chemical equilibrium modelling software MINEQL+ (Schecher and McAvoy, 1993).

\section{CALCULATION OF CHANGES IN NET MASSES OF ELEMENTS IN STREAM SEDIMENTS AND STREAM WATER (MASS)}

The areas above and below the time versus delta values $\left(c_{\mathrm{o}}-\mathrm{c}_{\mathrm{i}}\right)$ at point $\mathrm{C}$ ( $45 \mathrm{~m}$ beyond where the acid was added) during the eight hours were integrated numerically. This calculation determined the mass balance changes during the interaction of acidified water with the first $45 \mathrm{~m}$ of streambed.

\section{MODELLING THE ACIDIFICATION OF STREAM SEDIMENTS (MASS)}

Modelled interactions of cation adsorption and desorption from the stream sediment and subsequent resorption, or adsorption were based on the common reaction: 


$$
M e^{S}+H^{+} \longleftrightarrow M e^{+}+H^{S}
$$

The model assumes steady state equilibrium between metals in the stream solution $\left(\mathrm{Me}^{+}\right)$and homogenous stream sediment $\left(M e^{S}\right)$ throughout the stream before the episodic experimental acidification. The cation desorption from the stream sediment and its subsequent resorption are described as:

$$
\begin{aligned}
& \left(c_{\mathrm{Me}^{+}}\right)_{l}=k_{1} c_{\mathrm{H}^{+}} c_{\mathrm{Me}} \mathrm{S}-k_{2} c_{\mathrm{Me}^{+}} c_{\mathrm{H}} \mathrm{S} \\
& c_{\mathrm{H}^{+}}=c_{\mathrm{H}^{+}}^{0}+\alpha\left(c_{\mathrm{Me}^{+}}^{0}-c_{\mathrm{Me}^{+}}\right)
\end{aligned}
$$

where, $c_{H_{+}}$is the concentration of hydrogen ions in the stream water, $c_{M e+}$ is the concentration of the modelled cation in the streamwater, and $c_{M e}{ }^{S}$ and $c_{H}{ }^{S}$ are the leachable concentrations of the modelled cation $\mathrm{Me}^{+}$and $\mathrm{H}^{+}$sorbed to the solid phase (sediment), respectively. The $k_{i}$ values are rate constants. The parameter $\alpha$ reflects the proportional charge of the modelled ion and the relative loss of $\mathrm{H}^{+}$in the solution corresponding to all other solutes that are being desorbed at the same time as the modelled $\mathrm{Me}^{+}$. The concurrent desorption of other cations follows from Eqn. (3) and is consistent with the behaviour of modelled $\mathrm{Me}^{+}$. This formulation assumes a stream velocity that permits solution-sediment equilibration. The changes of $\mathrm{Me}^{+}$and $\mathrm{H}^{+}$concentrations are given by the derivative with respect to distance downstream, $l$. The time to any state is determined by the amount of exchangeable $\mathrm{Me}$ on the sediment, $c_{\mathrm{Me}}{ }^{\mathrm{s}}$. For the whole stream length, conservation of mass yields

$$
\left(c_{M e}\right)_{t}=-\left(c_{M e^{+}}\right)_{l} \quad d t=\frac{d l}{v}
$$

where $v$ is the stream velocity $\left(\mathrm{m} \mathrm{s}^{-1}\right)$. The temporal change of the cation concentration in sediment at any distance $(l)$ from the point of the acid addition corresponds to enrichment or depletion of $c_{\mathrm{Me}+}$, the element of interest.

$$
\left(\int_{0}^{L} c_{M e^{S}} d l\right)_{t}=c_{M e^{+}}^{0}-c_{M e^{+}}(L, t)
$$

This means that:

$$
c_{M e^{S}}(l, \tau)=c_{M e^{S}}^{0}-\int_{0}^{\tau}\left(c_{M e^{+}}(l, t)\right)_{l} d t
$$

The concentration of the $\mathrm{H}^{+}$sorbed on the solid phase at any time is:

$$
c_{H^{S}}=c_{H^{S}}^{0}+\alpha \int_{0}^{\tau}\left(c_{M^{+}}\right)_{l} d t
$$

Using Eqns, (5), (6) and (7), the solution of Eqn. (2) is:

$$
\begin{gathered}
c_{M e^{+}}(L, \tau)=e^{-z}\left[c_{M e^{+}}^{0}+k_{1}\left(c_{H^{+}}^{0}+\alpha c_{M e^{+}}^{0}\right) .\right. \\
\left.\int_{0}^{L}\left(c_{M e^{S}}^{0}-\int_{0}^{\tau}\left(c_{M e^{+}}(l, t)\right)_{l} d t\right) c^{z} d l\right] \\
z=\alpha\left(k_{2}-k_{1}\right) \int_{0}^{\tau}\left(c_{M e^{+}}(l, t)-c_{M e^{+}}^{0}\right) d t+\alpha k_{1} c_{M e^{S}}^{0} l+k_{2} c_{H}^{0} s
\end{gathered}
$$

Equation (8) was solved iteratively with respect to $t$. The derivative of $c_{\mathrm{Me}^{+}}$with respect to $l$ was obtained from Eqn. (2) in the previous time step. This approach was consistent with the physical aspects of the experiment. The flowing water interacts with a static solid phase that may be represented with respect to time in small time steps as:

$$
\left(c_{M e^{S}}(l, t+1)\right)_{t}=-\left(c_{\mathrm{Me}^{+}}(l, t)\right)_{l}
$$

This approach to modelling desorption and adsorption in a small stream enabled more accurate results than by using purely numerical methods. This dynamic model was based on mass-balance. The input parameters (rate constants) must be calibrated empirically against data from a specific stream (in this case, Lesni Potok). It is, however, a general model, containing processes that can be parameterised. The various $k_{i} \mathrm{~s}$ correspond to the adsorption and desorption processes and would have different values in other systems. Metabolic processes of living organisms on the solid and in the liquid phases were assumed to have a negligible impact on the metals being considered.

\section{Results}

$\mathrm{pH}$

The $\mathrm{pH}$ of the stream water above the acid addition was 4.8. After 3.5 hours of acid addition, $\mathrm{pH}$ was nearly 3.2 at points $\mathrm{A}$ and $\mathrm{B}, 3.5$ at point $\mathrm{C}$, and 3.7 at point $\mathrm{D}$ (Fig. 1). The $\mathrm{pH}$ value $\sim 3.2$ occurred at point $\mathrm{A} 20$ minutes after the start of the experiment and remained constant until the acid addition was stopped at $\mathrm{t}=4$ hours. At point $\mathrm{B}$, the $\mathrm{pH}$ value reached $\sim 3.2$ after three hours of acidification and remained at 3.2 until the end of the addition. It required nearly three hours to acidify the first $20 \mathrm{~m}$ of the stream to $\mathrm{pH}$ value $\sim 3.2$. At 4.25 hours (15 minutes after the end of the addition), the $\mathrm{pH}$ at point $\mathrm{A}$ recovered to 4.62 , and after an additional 30 minutes, $\mathrm{pH}$ was almost back to its initial value. At point $\mathrm{B}$ the $\mathrm{pH}$ increased during the first 15 minutes of the recovery to 3.9. After four hours of recovery, $\mathrm{pH}$ increased only to 4.55. The increase in $\mathrm{pH}$ was slower during the recovery period than the reduction during the acidification phase (Fig. 1). 


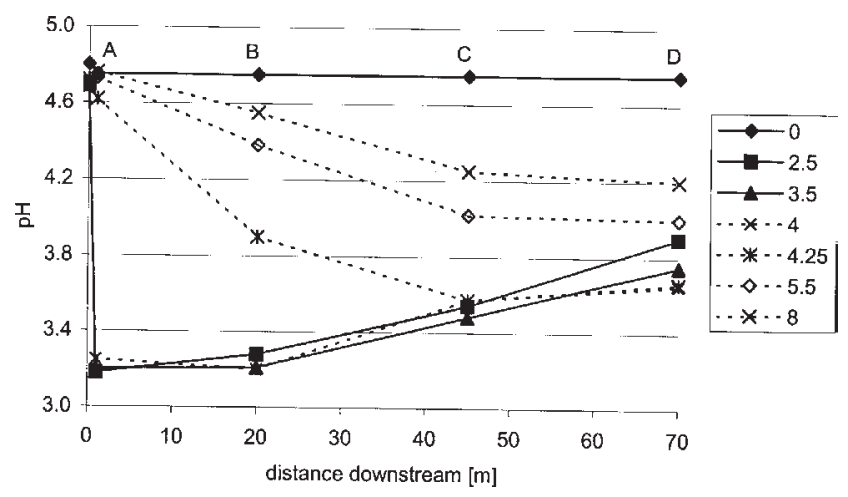

Fig. 1. Streamwater $p H$ at sites in the experimental stream reach. Solid lines represent changes during the acidification phase; dashed lines represent changes during the recovery. The number in the explanation is time (hours) from the beginning of experiment.

\section{ANIONS}

A pH of 3.2 caused by the addition of the $\mathrm{HCl}$ to water with an original $\mathrm{pH}$ of about 4.8 should add about $610 \mu \mathrm{eq} \mathrm{Cl}$ $\mathrm{L}^{-1}$ to the water. The $\mathrm{Cl}^{-}$concentration initially was 107 $\mu$ eq $\mathrm{L}^{-1}$ should have increased to about $720 \mu \mathrm{eq} \mathrm{L}^{-1}$ if $\mathrm{Cl}^{-}$ were conservative in the stream. The maximum $\mathrm{Cl}^{-}$measured was $540 \mu \mathrm{eq} \mathrm{L}^{-1}$, so either the minimum $\mathrm{pH}$ was slightly higher than measured ( $\mathrm{pH}$ should be 3.35 for the maximum measured $\mathrm{Cl}^{-}$) or $\mathrm{Cl}^{-}$was underestimated. There are no data for $\mathrm{Cl}$ at point $\mathrm{A}$ but at point $\mathrm{C}(45 \mathrm{~m}) \mathrm{Cl}^{-}$reached 258 $\mu$ eq $\mathrm{L}^{-1}$ after 15 minutes, $536 \mu \mathrm{eq} \mathrm{L}^{-1}$ after 1 hour and remained at $\sim 540 \mu \mathrm{eq} \mathrm{L}^{-1}$ until the end of the acidification. Ten minutes after the acid addition ended (4.25 hours from the start), $\mathrm{Cl}^{-}$concentration at point $\mathrm{C}$ decreased to $403 \mu \mathrm{eq}$ $\mathrm{L}^{-1}$. Three hours later, the concentration of $\mathrm{Cl}^{-}$had decreased to its initial value, $\sim 110 \mu \mathrm{eq} \mathrm{L}^{-1}$ at point $\mathrm{C}$ (Table 2). The water's residence time in the experimental reach was approximately 15 minutes.

Sulphate, the most abundant anion (1450 $\left.\mu \mathrm{eq} \mathrm{L}^{-1}\right)$, decreased by $4 \%\left(51 \mu \mathrm{eq} \mathrm{L}^{-1}\right)$ at point $\mathrm{C}$ during the first 15 minutes of the experiment. After reaching its minimum value (1400 $\left.\mu \mathrm{eq} \mathrm{L}{ }^{-1}\right), \mathrm{SO}_{4}{ }^{2-}$ started to increase gradually. During the recovery stage, the $\mathrm{SO}_{4}{ }^{2-}$ reached its maximum concentration $\left(1,463 \mu \mathrm{eq} \mathrm{L} \mathrm{L}^{-1}\right)$ six hours after the start of the acid treatment. Thereafter, it remained virtually constant ( $\sim 1455 \mu \mathrm{eq} \mathrm{L} \mathrm{L}^{-1}$ ) to the end of experiment (Fig. 2).

Nitrate increased slightly above background levels during the acidification experiment and decreased slightly during the recovery but the total variation was only $25 \mu \mathrm{eq} \mathrm{L}^{-1}$. This variation is less than the increase in $\mathrm{NO}_{3}{ }^{-}$during high discharge events. At point $\mathrm{C}, \mathrm{F}^{-}$concentration increased from 35 to 44 meq $\mathrm{L}^{-1}$, one hour after the acidification started and than decreased to slightly above background values even as the $\mathrm{pH}$ continued to decline (Table 2).
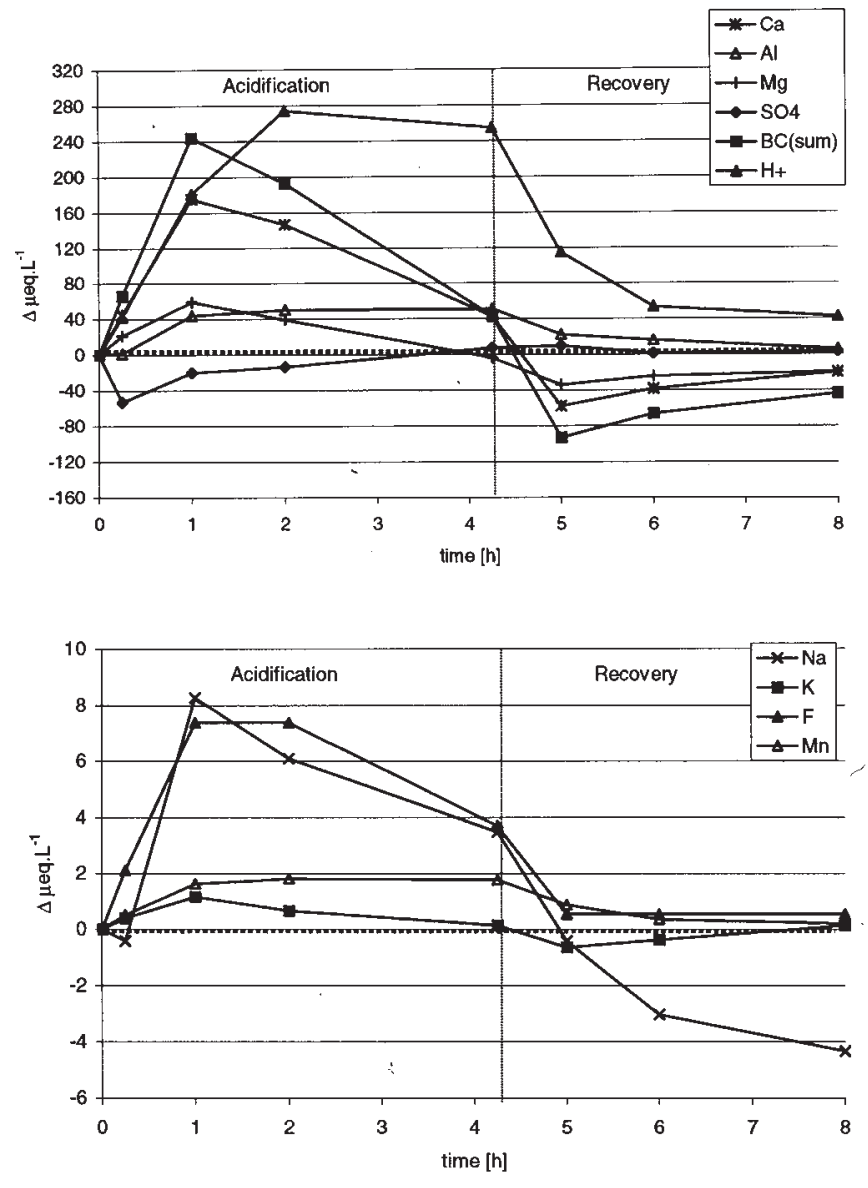

Fig. 2. The delta concentrations of dissolved analytes $\left(c_{i}-c_{0}\right.$; in $\mu e q$ $\left.L^{-1}\right)$ at point $C, 45 \mathrm{~m}$ below the point of acid addition. The dashed line represents no change. $B C=$ the sum of base cations $(\mathrm{Ca}, \mathrm{Mg}$, $\mathrm{Na}$, and $\mathrm{K}$ ).

\section{BASE CATIONS}

Concentrations of $\mathrm{Ca}$ and $\mathrm{Mg}$ increased significantly and rapidly. Calcium release neutralised the most acid; its concentration increased by $25 \%\left(175 \mu \mathrm{eq} \mathrm{L}^{-1}\right)$ at maximum concentration. Magnesium concentration increased rapidly but only to a maximum of $11 \%\left(58 \mu \mathrm{eq} \mathrm{L}^{-1}\right)$. In the first $20 \mathrm{~m}$ of the stream, sources of $\mathrm{Ca}$ and $\mathrm{Mg}$ were depleted after the first hour of the acidification and their concentrations in the solution gradually decreased (Fig. 2). Shortly after the acidification ceased $(\mathrm{t}=4.25 \mathrm{hrs}), \mathrm{Ca}$ and $\mathrm{Mg}$ concentrations decreased below their background values (at $\mathrm{t}=0$ ) and then started to increase slowly toward but not to the background concentration. The correlation between $\mathrm{Ca}$ and $\mathrm{Mg}$ for all samples was $\mathrm{R}=0.97$. However, at $\mathrm{t}=4$ hours at point $\mathrm{B}$, the concentration of $\mathrm{Mg}$ reached background concentration, indicating steady state equilibrium between the stream and sediment, but with the exchange complex depleted of $\mathrm{Mg}$ and no desorption (Fig. 2). Desorption of Ca was very low by this time (e.g. four 


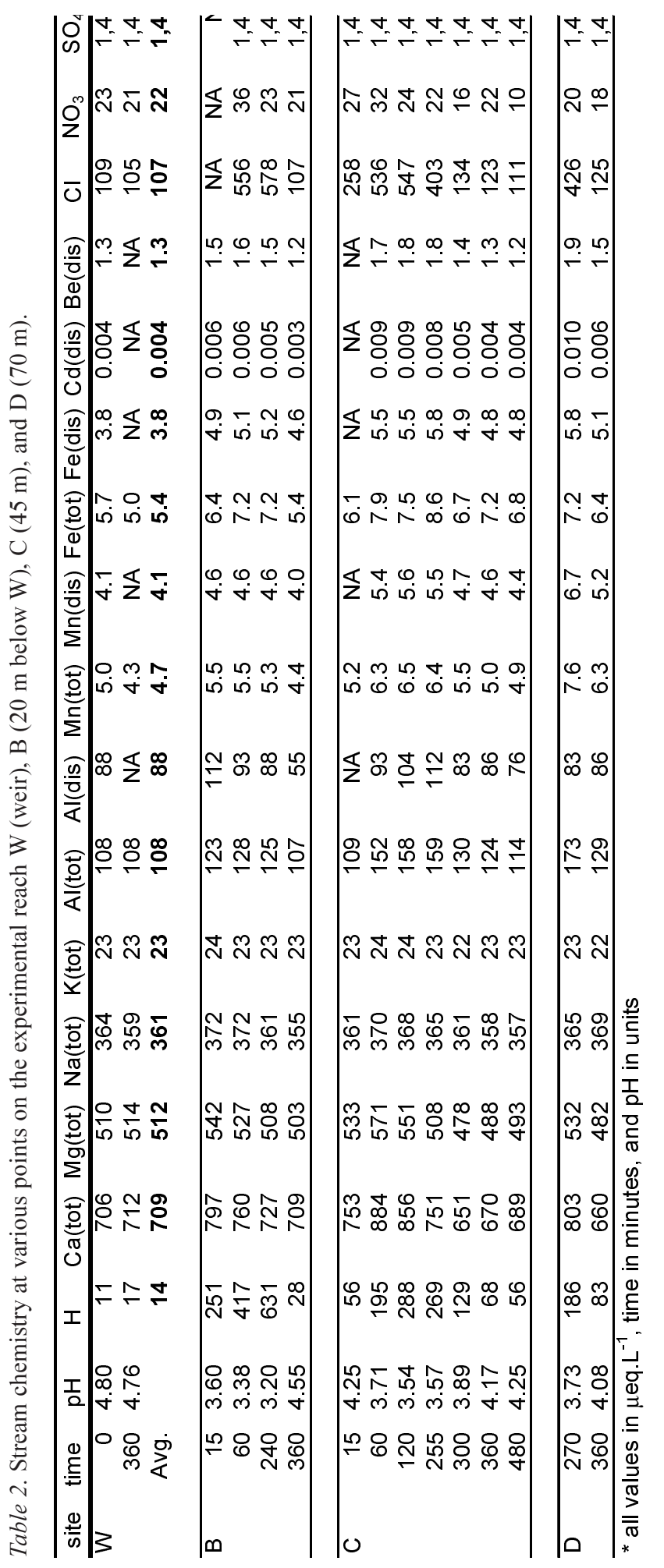

hours at Point $\mathrm{B}$ ). The concentrations of $\mathrm{Ca}$ and $\mathrm{Mg}$ for the entire sample group were insignificantly related to $\mathrm{H}^{+}$.

The concentration of $\mathrm{Na}$ did not vary significantly during the experiment. The maximum increase of $\mathrm{Na}$ concentration at point $\mathrm{C}$ was $2 \%\left(8 \mu \mathrm{eq} \mathrm{L}^{-1}\right)$. The maximum increase for $\mathrm{K}$ concentration was only $1 \mu \mathrm{eq} \mathrm{L}^{-1}$ and its contribution (ca. $20 \mu \mathrm{eq} \mathrm{L}^{-1}$ ) to the sum of cations is negligible.

\section{ALUMINUM}

The Al(tot) concentration did not change significantly during the first 15 minutes of the acidification but then increased about $50 \%$ (Fig. 3) and stabilised for three hours. The Al concentration in filtered samples $\mathrm{Al}$ (dis) was still increasing at four hours at point $\mathrm{C}$. The $\mathrm{Al}(\mathrm{dis})$ increased a maximum of $35 \%\left(23 \mu \mathrm{eq} \mathrm{L}^{-1}\right)$. After the acid addition, the concentration of both $\mathrm{Al}$ (tot) and $\mathrm{Al}$ (dis) decreased, but Al(tot) did not reach the initial concentration. Al(dis) decreased below background during the recovery. Although lower $\mathrm{pH}$ produced higher $\mathrm{Al}$ (dis), the statistical relationship was poor. The dominant species of Al before the experiment were $\mathrm{AlF}^{2+}$ and $\mathrm{AlF}_{2}{ }^{+}$. Over $70 \%$ of the $\mathrm{Al}$ (dis) concentration was $\mathrm{AlF}^{2+}$ during the experiment. $\mathrm{AlF}_{2}{ }^{+}$accounted for $\sim 18 \%$ before the treatment but decreased to $10 \%$ as $\mathrm{Al}$ reached its highest concentration $(\mathrm{t}=4.25 \mathrm{hrs})$. Other species of $\mathrm{Al}$ were $\mathrm{Al}^{3+}, \mathrm{AlF}_{3 \mathrm{aq}}$ and $\mathrm{AlSO}_{4}^{+} \cdot \mathrm{Al}^{3+}$ became more important at the highest $\mathrm{Al}(\mathrm{dis})$ concentration.

\section{TRACE METALS}

Concentrations of dissolved and particulate manganese were low (c. $4 \mu \mathrm{eq} \mathrm{L} \mathrm{L}^{-1}$ ) and increased only by 1 to $2 \mu \mathrm{eq} \mathrm{L}^{-1}$ at the lowest $\mathrm{pH}$. Total and filtered Mn concentrations (tot) and (dis) were highly correlated during the acidification ( $\mathrm{R}=$ 0.95 ) and both correlated strongly with Fe and Al. Concentrations of (tot) and (dis) Fe were low and increased only by $\sim 2 \mu \mathrm{eq} \mathrm{L}^{-1}$ during the acidification. During the recovery stage $\mathrm{Fe}$ (tot) and $\mathrm{Fe}$ (dis) concentrations remained higher than initial concentrations. The Be concentration increased by up to $0.5 \mu \mathrm{eq} \mathrm{L} \mathrm{L}^{-1}$ (Fig. 3) at the peak of acidity and then decreased to background during recovery. The correlation of $\mathrm{Be}$ with $\mathrm{Al}$ was significant $(\mathrm{R}=0.88)$, as it was with $\mathrm{Mn}$ (tot), $\mathrm{Mn}$ (dis), $\mathrm{Fe}$ (tot) and $\mathrm{Fe}$ (dis). Cadmium concentration doubled at point $\mathrm{C}$ but its contribution to acid neutralisation was trivial.

\section{MODELLING THE ACIDIFICATION OF STREAM SEDIMENT (MASS) - STREAM WATER-SUBSTRATE INTERACTION}

The distribution of cations (including $\mathrm{H}^{+}$) and anions between the liquid and solid phases is a result of ion 

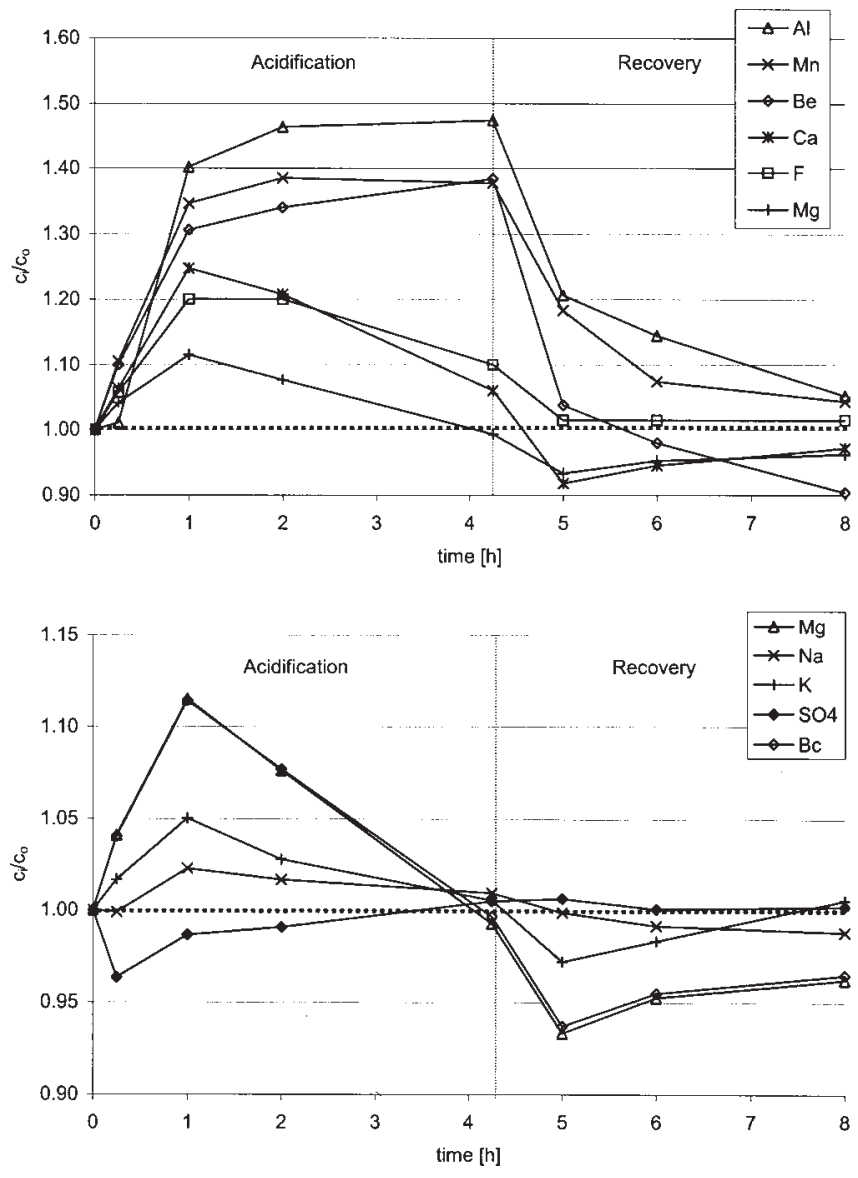

Fig. 3. The relative change ( $c / c_{0}$ equivalents/equivalents) of concentrations of dissolved analytes versus time at point $C, 45 \mathrm{~m}$ below the acid addition point, $(B c=C a+M g+K)$.

exchange (adsorption or desorption) and dissolution or precipitation. The concentrations and proportions of ions in solution affect these interactions. The concentrations of base cation metals in bulk sediment are generally much higher than in solution. However, not all of the metals are exchangeable. The limited sorption sites on the solid surfaces have different binding energies and affinities for different ions. The MASS model must be parameterised for each element using appropriate values of rate constants $\left(k_{i} \mathrm{~s}\right)$.

The dynamic model describes only adsorption and desorption of cations. No dissolution (e.g. of Al) is included. The fit between experimental observations of $\mathrm{Ca}$ and the modelled value is shown at Fig. 7. A good match of the modelled dependencies for $c_{M e^{+}}$with the experimental data was obtained with $k_{1} / k_{2}=1.25$ and $\alpha=2.4$. The modelled decrease of $c_{H^{+}}$and increase of $c_{H}{ }^{S}$ is not in good agreement with the measurements without taking into account the depletion of $\mathrm{H}^{+}$by other desorbed cations and dissolved $\mathrm{Al}$. This additional interaction of $\mathrm{H}^{+}$with other cations through ion exchange, $\mathrm{Al}, \mathrm{Fe}, \mathrm{Mn}$ dissolution and sulphate adsorption is calibrated through the $\alpha$ parameter.

\section{Discussion}

\section{ANIONS}

The $\mathrm{SO}_{4}{ }^{2-}$ concentration declined rapidly suggesting adsorption of the $\mathrm{SO}_{4}^{2-}$ during the acidification phase (Fig. 3). As the surfaces of the in-stream solid phases gain positive charge by adsorption of $\mathrm{H}^{+}$, the $\mathrm{SO}_{4}^{2-}$ becomes bound to the solid phase because of the increasingly positive surface charge (Nodvin et al., 1986). As the concentration of the $\mathrm{H}^{+}$ ions in the stream and on the substrate decreases, $\mathrm{SO}_{4}{ }^{2-}$ is desorbed to the solution. The $\mathrm{SO}_{4}{ }^{2-}$ concentration normally increases during high discharge events (Table 1). The total variation of $\mathrm{SO}_{4}{ }^{2-}$ during the experiment was about $50 \mu \mathrm{eq} \mathrm{L}^{-1}$, substantially less than the variation seen during low and high flow, $206 \mu$ eq $\mathrm{L}^{-1}$, the highest of all measured parameters. Consequently it is concluded that a stream water - sediment interaction plays only a small role in buffering $\mathrm{SO}_{4}{ }^{2-}$ concentration. The mean free $\mathrm{F}^{-}$concentration decreased by $1 \mu \mathrm{eq} \mathrm{L}^{-1}$ from 1994 to 1999 but, during variable discharge, it ranged from 37 (low discharge) to $43 \mu \mathrm{eq} \mathrm{L} \mathrm{L}^{-1}$. During the artificial acidification, $\mathrm{F}^{-}$increased comparably. Fluoride may be released from exchange sites as $\mathrm{H}^{+}$displaces $\mathrm{OH}^{-}$. An additional explanation for the increase in $\mathrm{F}$ at lower $\mathrm{pH}$ is that as $\mathrm{Al}$ is liberated from the stream substrate during acidification, F complexed to the solid is released to the solution. Further, at lower $\mathrm{pH}, \mathrm{F}$ complexed with Al should become liberated as Al speciation shifts toward $\mathrm{Al}^{3+}$.

\section{CATIONS}

The LP surface water has high ionic strength due to a combination of chemical weathering and high evapotranspiration in the catchment. The mean annual concentrations of $\mathrm{Ca}$ and $\mathrm{Mg}$ in the surface water have decreased from 1994 to 1999 and they increase during high discharge events (Table 1). The $\mathrm{Ca}$ and $\mathrm{Mg}$ concentrations in the experiment did not exceed the range in the long-term monitoring data (Table 1). The range of the $\mathrm{Ca} / \mathrm{Mg}$ ratio (1.36-1.55) during the experiment is within the range of the $\mathrm{Ca} / \mathrm{Mg}$ ratio (1.2-2.22) determined during the seven years of monitoring the LP catchment. The increased $\mathrm{SO}_{4}{ }^{2-}$ and $\mathrm{H}^{+}$concentrations induced the desorption of $\mathrm{Ca}$ and $\mathrm{Mg}$. Initially, release of the divalent base cations $\mathrm{Ca}$ and $\mathrm{Mg}$ was the most important component of the acid neutralisation. As this reservoir became depleted, release of more Al contributed to the neutralisation of the acid input. $\mathrm{The} \mathrm{Ca} / \mathrm{Mg}$ ratio was highest at one to two hours, indicating 
desorption of $\mathrm{Ca}$ in greater proportion to $\mathrm{Mg}$ from the stream substrate (Fig. 4). The lowest ratio occurred at five hours, representing the start of the $\mathrm{Ca}$ and $\mathrm{Mg}$ resorption during the recovery stage. At 5 hours (Fig. 4), Mg was resorbed in greater proportion to its stream concentration than was $\mathrm{Ca}$. Two hours after the acid addition stopped, $\mathrm{Ca}$ and $\mathrm{Mg}$ concentrations started slowly to increase (Fig. 2). Although the $\mathrm{Ca} / \mathrm{Mg}$ ratio recovered to its original value by the end of the experiment, the concentrations had not. The rate of recovery was slower than the mobilisation of base cations during the acidification phase. The shape of the curve for "sum of base cations (BC)" through time (acidification and recovery) is consistent with the conceptual model of Norton et al. (1999).

Sodium behaved contrary to $\mathrm{Ca}, \mathrm{Mg}$, and $\mathrm{K}$. The longterm concentration of $\mathrm{Na}$ correlates negatively with discharge (Table 1) but was unaffected in the experiment. High discharge events normally slightly enhance the export of $\mathrm{K}$ from the catchment but the difference between the mean concentrations for low and high discharges is small (Table 1). The concentration of $\mathrm{K}$ changed less than $1 \mu \mathrm{eq} \mathrm{L}^{-1}$ from the background value. Sodium and $\mathrm{K}$ are relatively unaffected by in-stream processes.

The mean $\mathrm{Al}$ (tot) concentration in the LP surface water has decreased from $92 \mu \mathrm{eq} \mathrm{L} \mathrm{L}^{-1}$ in 1994 to $83 \mu \mathrm{eq} \mathrm{L}^{-1}$ in 1999 as $\mathrm{SO}_{4}{ }^{2-}$ and $\mathrm{H}^{+}$have declined. The concentration of $\mathrm{Al}$ (tot) in the surface water increased as $\mathrm{pH}$ decreased (Table 1). The mean values of Al(tot) for low and high flow discharges differ by $29 \mu \mathrm{eq} \mathrm{L}^{-1}$. During the first 15 minutes of the experimental acidification, little $\mathrm{Al}$ (tot) was mobilised from the substrate, compared to $\mathrm{Ca}$ or $\mathrm{Mg}$. The concentration of Al(tot) started to increase in the first hour of the acidification and reached its maximum after four hours of acidification. The increase in $\mathrm{Al}$ (tot) during the experiment was approximately twice the natural range (Tables 1 and 2 ). The concentrations of $\mathrm{F}^{-}$in the surface water increased at higher flows, likely enhancing Al mobility by formation of Al-F complexes. The Al(tot) was higher than mean values for any flow in the 1994-2000 period. It is concluded that Al stream chemistry is affected by water-sediment interaction, principally decreasing the rate and magnitude of episodic acidification and recovery.

\section{TRACE METALS}

The export of $\mathrm{Mn}$ from the catchment has decreased by $5 \mu \mathrm{eq} \mathrm{L}^{-1}$ from 1994 to 1999 . The highest mean concentrations were at low discharge (Table 1). Iron in surface water normally decreases with increasing discharge and decreasing $\mathrm{pH}$. Thus, the small increase of $\mathrm{Fe}$ in the experiment suggests some in-stream release of Fe. Beryllium and $\mathrm{Cd}$ were normally mobilised during high discharge events (Table 1). Their concentrations during the experiment rose to relatively high values, suggesting that the stream sediments may contribute much of the $\mathrm{Be}$ and $\mathrm{Cd}$ at high flow. On a percentage basis, $\mathrm{Cd}$ was the most mobilised metal. Its concentration increased rapidly due to the elevated $\mathrm{H}^{+}$and decreased immediately as $\mathrm{pH}$ rose at the end of experiment, falling below the initial concentration. The average concentrations of $\mathrm{Cd}$ and $\mathrm{Be}$ have decreased in the surface waters of LP between 1994-1999 (Table 1) (Navrátil et al., 2002). Possible causes are decreased deposition of Be and Cd to the catchment (Skrivan et al., 2000) and the streamwater $\mathrm{pH}$ increase.

The Be geochemistry at LP has been reported in detail by Skrivan et al. (1993, 1994 and 2000) and Navrátil (2000, 2002). The most important species of Be in the LP surface water were $\mathrm{Be}^{2+}$ and $\mathrm{BeF}^{+}$(Navrátil, 2000). Before the acidification experiment, $\mathrm{Be}^{2+}$ was $\sim 10 \%$ higher than $\mathrm{BeF}^{+}$, $\mathrm{BeF}_{2}, \mathrm{BeSO}_{4}$ and $\mathrm{BeOH}^{+}$accounted for $<3 \%$ during the experiment. During the acidification phase, $\mathrm{Be}^{2+}$ became more dominant as the $\mathrm{F}$ became preferentially bound to $\mathrm{Al}$, particularly at the end of the acidification. As the Al concentration decreased during the recovery stage, the relationship between the $\mathrm{Be}^{2+}$ and $\mathrm{BeF}^{+}$reversed. Similar behaviour of Be species was observed during episodic events at the LP catchment in 1999 (Navrátil, 2000).

\section{ACID NEUTRALISATION MECHANISMS THROUGH} TIME

The stream substrate at LP is involved in three important mechanisms of acid neutralisation:

(1) adsorption of $\mathrm{SO}_{4}^{2-}$

(2) ion exchange of $\mathrm{H}^{+}$for the divalent base cations $\mathrm{Ca}^{2+}$ and $\mathrm{Mg}^{2+}$ on the cation exchange sites of the stream substrate, and

(3) ion exchange of $\mathrm{H}^{+}$for $\mathrm{Al}^{3+}$ on the cation exchange sites of the stream substrate or dissolution of a solid phase $\mathrm{Al}(\mathrm{OH})_{3}$ of the stream substrate.

The contribution of the individual elements to acidneutralisation (Fig. 6) early in the experiment was $\mathrm{SO}_{4}^{2-}$ $>\mathrm{Ca}>\mathrm{Mg}>\mathrm{Al}(\mathrm{t}=0.25 \mathrm{~h})$, then $\mathrm{Ca}>\mathrm{Mg}>\mathrm{Al}>\mathrm{SO}_{4}^{2-}$ $(\mathrm{t}=1 \mathrm{~h})$, and finally $\mathrm{Al}>\mathrm{Ca}>\mathrm{Mg}>\mathrm{SO}_{4}{ }^{2-}(\mathrm{t}=4 \mathrm{~h})$. The maximum acid neutralisation by base cation release and $\mathrm{SO}_{4}{ }^{2-}$ adsorption was about $170 \mu \mathrm{eq} \mathrm{L}^{-1}$. The adsorption of $\mathrm{SO}_{4}{ }^{2-}$ was the fastest process. However, the total contribution of this process $(59 \mu \mathrm{eq})$ to neutralisation of the acid over the $70 \mathrm{~m}$ stretch of stream was small compared to that of $\mathrm{Ca}$

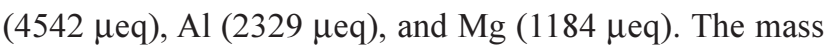




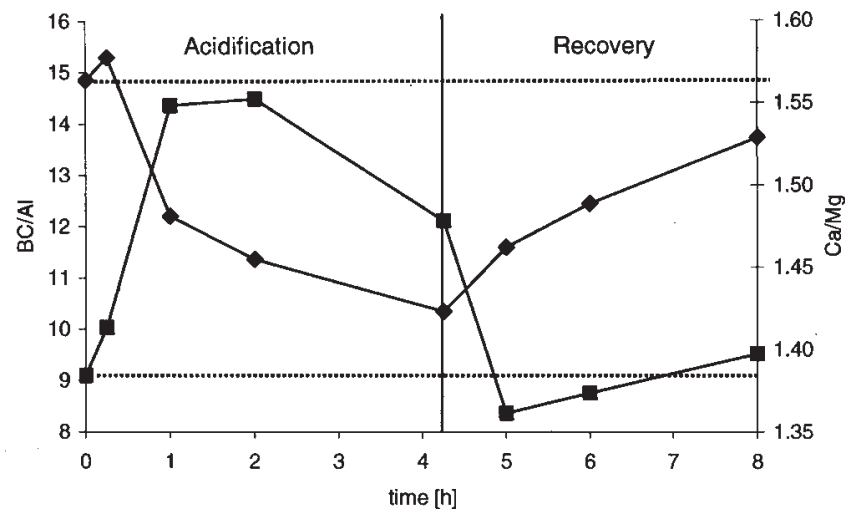

Fig. 4. The Ca/Mg ratio (equivalents/equivalents) (squares, right $Y$ axis) and $B C / A l$ (dis) ratio (equivalents/equivalents) (diamonds, left $Y$ axis) versus time at point $C, 45 \mathrm{~m}$ below the acid addition point.

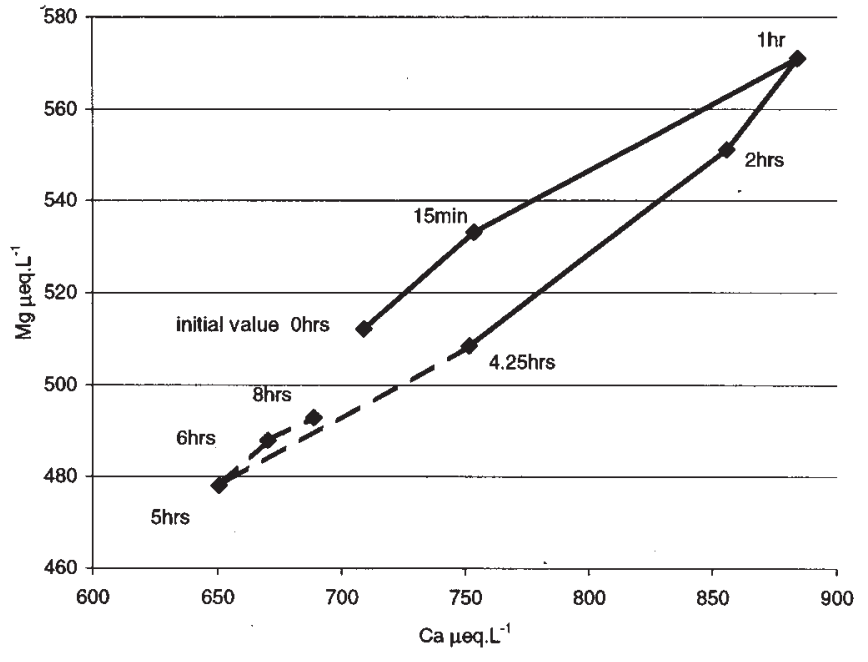

Fig. 5. The concentration of Ca versus $\mathrm{Mg}$ at point $C, 45 \mathrm{~m}$ below the acid addition point. The solid line represents acidification; the dashed line represents the recovery; numbers represent time in hours.

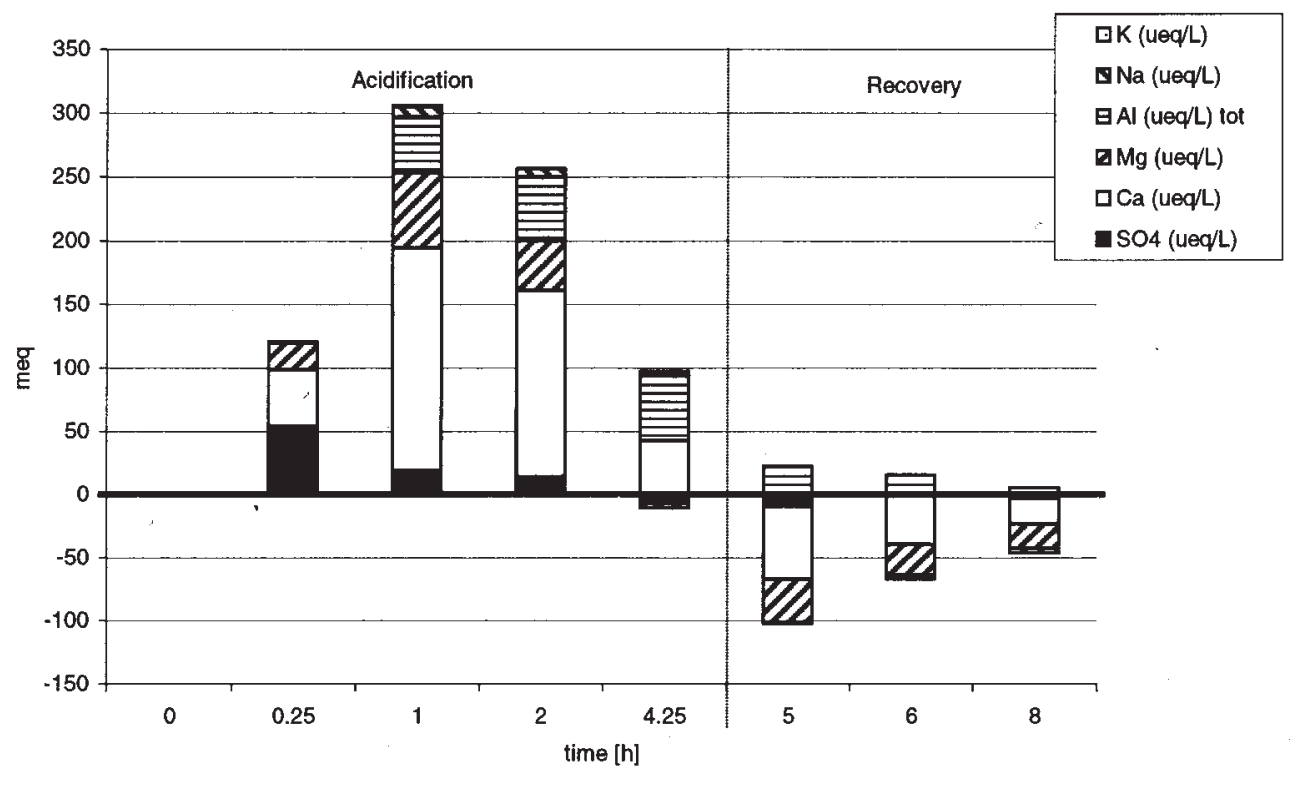

Fig. 6. Acid neutralisation through time at point $C, 45 \mathrm{~m}$ below the acid addition point. The $x$-axis is not proportional.

of BCs $(5961 \mu \mathrm{eq})$ desorbed from the stream sediment exceeded the integrated mass of BCs resorbed back to the substrate over a similar time; recovery was slower than acidification. Even after $\mathrm{Cl}$ and $\mathrm{SO}_{4}{ }^{2-}$ concentrations had returned to background values, $\mathrm{Ca}, \mathrm{Mg}$, and $\mathrm{Al}$ had not recovered. $\mathrm{Mg}$ had the highest resorption to substrate (approximately $790 \mu \mathrm{eq}$ or $67 \%$ of the desorbed amount) during the 4-hour recovery. Of the desorbed $\mathrm{Ca}, \mathrm{Na}$, and $\mathrm{K}$, $24 \%, 39 \%$ and $39 \%$, respectively, were resorbed. But the contribution of $\mathrm{Na}$ and $\mathrm{K}$ to the total acid neutralisation was minor. Sodium and $\mathrm{K}$ are $4 \%$ and $10 \%$, respectively, of the total base cations extracted from soil but only $1 \%$ and $2 \%$, respectively, from stream sediment with $0.1 \mathrm{M} \mathrm{HNO}_{3}$ (Navrátil, unpublished). Consequently, little $\mathrm{Na}$ and $\mathrm{K}$ are available for ion exchange in the stream.

The Fe and Mn were exported in lower amounts (195 $\mu$ eq and $83 \mu \mathrm{eq}$, respectively). If acid neutralisation had not occurred, the $\mathrm{pH}$ at point $\mathrm{C}$ would have decreased to 3.75 , $3.31,3.27$ and 3.45 at times $0.25,1,2$ and 4.25 hours, respectively. During recovery, the $\mathrm{pH}$ would increase faster 

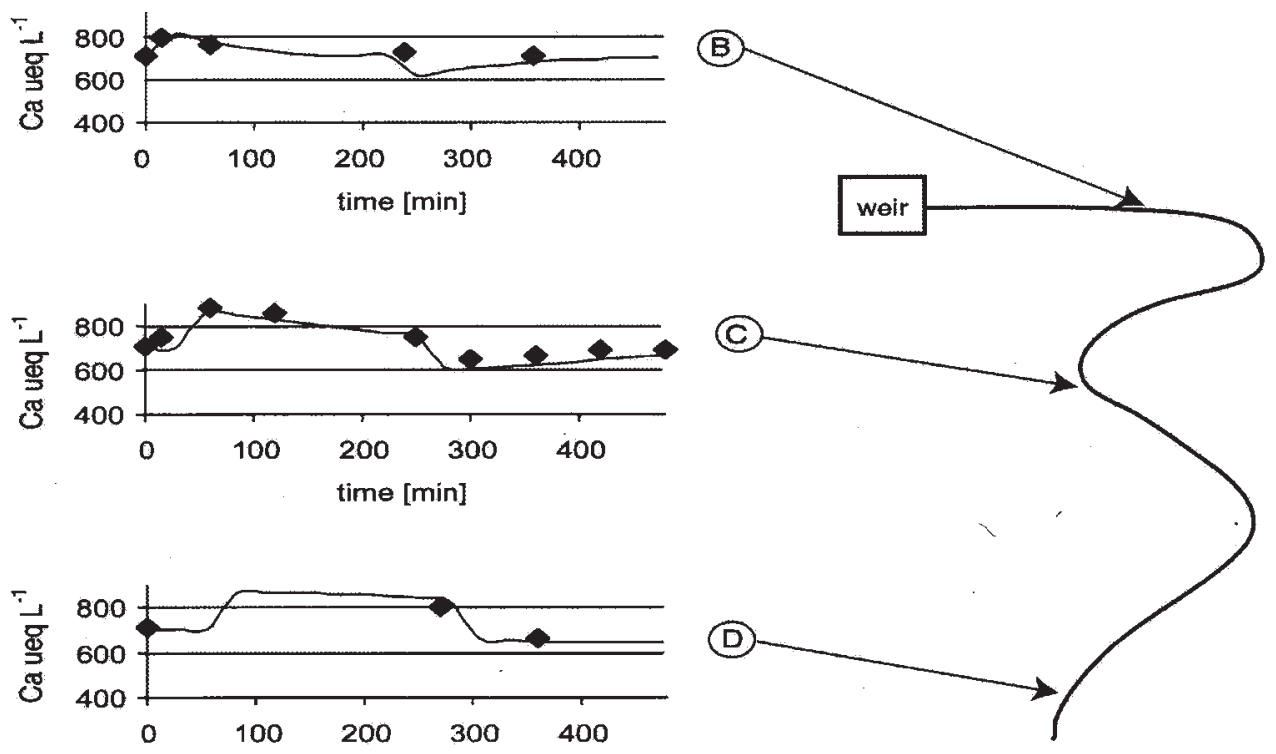

Fig. 7. Measured Ca concentration (diamonds) and modelled response for Ca concentration (solid line) at points $B, C$, and $D$ versus time.

if the resorption of base cations and desorption of $\mathrm{SO}_{4}^{2-}$ had not occurred. The $\mathrm{pH}$ should have returned to its initial value (4.71) after 2 hours of recovery, based on $\mathrm{Cl}^{-}$ concentration, and assuming no sediment-water interaction.

\section{THE MASS MODELLED RESPONSE}

During the experimental acidification phase, the $\mathrm{pH}$ increased downstream toward the value prior to the acidification because of the interactions between the acidified water and the stream substrates. The acidic water caused desorption of exchangeable base cations and $\mathrm{Al}$ from the substrate and, therefore, $\mathrm{H}^{+}$was lost from solution. Increased concentrations of the BCs in water may then shift the equilibrium downstream between sediment and water if $\mathrm{pH}$ does not override the increased concentrations of cations. Some adsorption of excess cations may occur downstream. The dominant factor controlling the chemical changes in stream water is the concentration of $\mathrm{H}^{+}$. As the $\mathrm{pH}$ decreased to 3.5 , the concentrations of the divalent cations in the solution increased significantly. The $\mathrm{H}^{+}$ions were very competitive during ion exchange at the interface of hydrophilic oxide (silicate and alumosilicate) and organic matter surfaces and the aqueous solution. Sorption sites of the solid surfaces were unsaturated with bases during the experiment. If this were not true, there would have been no initial equilibrium (Eqn. 1). Concurrent with the cation desorption, polyvalent anions (mostly $\mathrm{SO}_{4}{ }^{2-}$ ) are sorbed (their concentration in solution decreases) as a result of increasing positive charge of the solid surfaces, caused by the increased concentration of $\mathrm{H}^{+}$in solution and on the exchange surface. A lag of the $c_{M e+}$ maxima (peak concentrations) at each sampling site is caused by lower mean effective stream flow velocity than was calculated from the measured discharge. This lower stream velocity corresponding to the modelled calculation can be attributed to water turbulence, non-homogeneous velocity within the stream and solute-substrate penetration (hyporheic infiltration).

\section{COMPARISON WITH OTHER EXPERIMENTS}

In all artificial stream acidification experiments where appropriate data have been collected, base cations are released by desorption, $\mathrm{Al}$ is dissolved from an $\mathrm{Al}$-rich phase or desorbed, and $\mathrm{SO}_{4}{ }^{2-}$ is adsorbed during the acidification trajectory. The amounts and proportions of base cations released differ among experiments, probably depending on the acidification status of the catchment soils prior to the experiment (and, thus, of the stream sediment properties) as well as the exchange properties (e.g. selectivity for a specific cation) of the stream substrate. During recovery, these reactions are reversible but have unequal rates so that the chemical recovery does not retrace the acidification trajectory. The rate of establishment of a new equilibrium during acidification is $\mathrm{SO}_{4}{ }^{2-}>$ base cations $>\mathrm{Al}$. The recovery process rates are more complex and less uniform from study to study. None of the studies has data taken over 
a sufficiently long period to determine when stream chemistry returns to normal at some specified distance downstream from the acid addition. For the LP study, the concentration of $\mathrm{Cl}$ returned to normal within two and eight hours at 20 and $50 \mathrm{~m}$ downstream, respectively. Yet the base cations had still not completely recovered. Al dynamics are even more complex, involving the probable precipitation of $\mathrm{Al}(\mathrm{OH})_{3}$ on the stream substrate, as well as recharging $\mathrm{Al}$ sites as part of the exchange acidity of the sediment. Water chemistry probably returns asymptotically to normal within several days. During the experiment, the stream was at the lower threshold for high discharge (Table 1) and acidic. The artificial depression of $\mathrm{pH}$ was dramatically below normal variations. Acid neutralisation under more normal episodic acidification would be somewhat less effective, but more prolonged. It is concluded that stream sediment has the ability to reduce the $\mathrm{pH}$ depression during acidification and prolong recovery through cation and anion exchange, and $\mathrm{Al}$ exchange, dissolution and precipitation.

\section{Conclusions}

In response to the addition of $\mathrm{HCl}$ directly to the stream at Lesni Potok, $\mathrm{F}^{-}$increased and $\mathrm{SO}_{4}{ }^{2-}$ decreased. This difference in behaviour must be caused by site-specific exchange mechanisms. The variation in free $\mathrm{F}^{-}$is likely to be caused by dissolution of particulate $\mathrm{Al}(\mathrm{OH})_{3}$ and release of exchangeable $\mathrm{F}$ at the lower $\mathrm{pH}$, rather than by changes in $\mathrm{Al}$ speciation. The $\mathrm{SO}_{4}{ }^{2-}$ behaviour is dominated by $\mathrm{pH}-$ related changes in anion exchange capacity, with adsorption increasing at lower $\mathrm{pH}$. During the recovery stage, the stream substrate desorbed $\mathrm{SO}_{4}{ }^{2-}$. This experiment supports the conclusions from Hruška et al. (2002) who examined the release of $\mathrm{SO}_{4}{ }^{2-}$ from other catchments in Europe. In general, atmospheric deposition rates of $\mathrm{SO}_{4}{ }^{2-}$ have decreased in Europe and North America. Excess $\mathrm{SO}_{4}{ }^{2-}$ in soils and stream sediment is being desorbed and exported from many catchments.

The experiment demonstrated the reversible exchange processes between $\mathrm{H}^{+}$and base cations, particularly $\mathrm{Ca}^{2+}$ and $\mathrm{Mg}^{2+}$. As the $\mathrm{Ca}-\mathrm{Mg}$ exchangeable pool became depleted, $\mathrm{Al}$ release gradually replaced $\mathrm{Ca}-\mathrm{Mg}$ release as the principal acid-neutralising mechanism. The $\mathrm{Ca} / \mathrm{Mg}$ ratio in the stream was highest during the acidification and lowest at the start of the recovery. During recovery, $\mathrm{Mg}$ resorbed faster than $\mathrm{Ca}$. The $\mathrm{BC} / \mathrm{Al}$ ratio increased at first but decreased sharply as $\mathrm{BCs}$ became depleted and $\mathrm{Al}$ mobilisation increased. The $\mathrm{BC} / \mathrm{Al}$ ratio did not return to its initial value during the recovery period. The reversible desorption of $\mathrm{BC}$, dissolution of $\mathrm{Al}$ and adsorption of $\mathrm{SO}_{4}{ }^{2-}$ delayed acidification, diminished the $\mathrm{pH}$ depression and prolonged the recovery. Recovery is slower than acidification, there is hysteresis in the pattern of recovery and the recovery lags behind the flushing of the added $\mathrm{Cl}$ (as $\mathrm{HCl}$ ).

During the acidification, $\mathrm{Al}^{3+}$ and $\mathrm{AlF}^{2+}$ become more important species of dissolved Al. Calculated Be speciation was controlled by abundance of the $\mathrm{Al}$ species, $\mathrm{pH}$, and the availability of free $\mathrm{F}^{-}$. Iron and $\mathrm{Mn}$ were both mobilised during the artificial acidification phase but their concentration normally decreases during natural episodic acidification events, likely because of dilution and oxidation of the Feand Mn-rich shallow groundwater. The mobilised Mn and $\mathrm{Fe}$, although increasing over $40 \%$ above their initial concentration, were unimportant as an acid-neutralising mechanism because of their low concentrations. Although clear evidence of resorption of $\mathrm{Al}, \mathrm{Fe}$, and $\mathrm{Mn}$ is lacking (no values below background), the recovery of these three elements to background values could be delayed by resorption.

A dynamic model (MASS - Modelling the Acidification of Stream Sediment) was developed. It reproduces the behaviour of the base cations that are involved in ion exchange equilibria. The master variables include $\mathrm{pH}$, which is controlled partly by anion exchange (primarily $\mathrm{SO}_{4}^{2-}$ ) and partly by dissolution or precipitation of $\mathrm{Al}(\mathrm{OH})_{3}$. MASS does not model the anion exchange or solid phase equilibria with $\mathrm{Al}(\mathrm{OH})_{3}$. The significant consistency between modelled and measured base cation concentrations suggests that the assumptions of the modelling approach may be realistic. Clearly, stream sediment (somewhat analogous to catchment soils) minimises the magnitude of episodic acidification and delays recovery.

\section{Acknowledgments}

This research was supported by a project of the Geological Institute of the Czech Academy of Science CEZ Z 3-013912, a project KONAKT ME 147 (to J. Veselý) and grant project ASCR B3013203 (to T. Navrátil). Navrátil was supported by the graduate study programme at Faculty of Science, Charles University (Czech Republic). Norton was supported by the U.S. Geological Survey (Grant 2001ME1481G). Thanks are due to M. Burian (Geological Inst. ASCR) for excellent analytical work and to D. Fottová and J. Veselý (Czech Geol. Survey) for their cooperation. For more information about the Lesni Potok catchment, visit http://www.gli.cas.cz/lesnipotok/. 


\section{References}

Hall, R., Likens, G.E., Fiance, S.B. and Hendrey, G.R., 1980. Experimental acidification of a stream in the Hubbard Brook Experimental Firest, New Hampshire. Ecology, 61, 976-989.

Hruška, J., Kohler, S. and Bishop, K., 1999. Buffering processes in a boreal dissolved organic carbon-rich stream during experimental acidification. Environ. Pollut., 106, 55-65.

Hruška, J., Moldan, F. and Krám, P., 2002. Recovery from acidification in central Europe -observed and predicted changes of soil and streamwater chemistry in the Lysina, catchment. Czech Republic. Environ. Pollut., 120, 261-274.

Kopácek, J., Veselý, J. and Stuchlík, E., 2001. Sulphur and nitrogen fluxes and budgets in the Bohemian Forest and Tatra Mountains during Industrial Revolution (1850-2000). Hydrol. Earth Syst. Sci., 5, 391-406.

Navrátil, T., 2000. Beryllium in waters of Czech forested ecosystems and the release of beryllium from granites. GeoLines, 12, 18-40.

Navrátil, T., SkYivan, P., Minarík, L. and Žigová, A., 2002. Beryllium Geochemistry in the Lesni Potok Catchment (Czech Republic), 7 Years of Systematic Study. Aquat. Geochem., 8, 121-133.

Nodvin, S.C., Driscoll, C.T. and Likens, G.E., 1986. The effect of $\mathrm{pH}$ on sulfate adsorption by a forest soil. Soil Sci., 142, 69-75.

Norton, S.A., Henriksen, A., Wathne, B.M. and Veidel, A., 1987. Aluminum dynamics in response to experimental additions of acid to a small Norwegian stream, Proc UNESCO/IHP-III Symp Acidification and Water Pathways Norw. Natl. Comm. for Hydrology, Bolkesjø, Norway, May 1987 Vol 1, 249-258.
Norton, S.A., Brownlee, J.C. and Kahl, J.S., 1992. Artificial acidification of a non-acidic and an acidic headwater stream in Maine, USA. Environ. Pollut., 77, 123-128.

Norton, S.A., Kahl, J.S. and Fernandez, I., 1999. Altered soil-soil water interactions inferred from stream water chemistry at an artificially acidified watershed at Bear Brook watershed, Maine USA. Environ. Monit. Assess., 55, 97-111.

Norton, S.A., Wagai, R., Navrátil, T., Kaste, J.M. and Rissberger, F.A., 2000. Response of a first-order stream in Maine to shortterm instream acidification. Hydrol. Earth Syst. Sci., 4, 383391.

Schecher, W.D. and McAvoy, D.C., 1992. A Software Environment for Chemical Equilibrium Modeling. Comput. Environ. Urban Syst., 16, 65-76.

Skrivan, P., Artner, P. and Kotková, P., 1993. Secondary anthropogenic contamination of surface streams through lithogenic beryllium, mobilized by acid atmospheric deposition. Acta Univ. Carolinae geologica, 37, 111-122.

Skrivan, P., Minarík, L., Burian, M. and Vach, M., 1994. Cycling of Beryllium in the Environment under Anthropogenic Impact. Scientia Agr. Bohemica, 25, 65-75.

Skrivan P., Navrátil, T. and Burian, M., 2000. 10 years of monitoring the atmospheric inputs at the ernokostelecko region, central Bohemia. Scientia Agr. Bohemica, 31, 139-154.

Tipping, E. and Hopwood, J., 1988. Estimating stream concentrations of aluminium released from streambeds during 'acid episodes'. Environ. Technol. Lett., 9, 703-712. 